\title{
New material from a huge specimen of Anteophthalmosuchus cf. escuchae (Goniopholididae) from the Albian of Andorra (Teruel, Spain): Phylogenetic implications
}

\author{
E. Puértolas-Pascual ${ }^{1,2 *}$, J.I. Canudo ${ }^{1,2}$, L.M. Sender ${ }^{2}$ \\ ${ }^{1}$ Grupo Aragosaurus-IUCA, Departamento de Ciencias de la Tierra, Facultad de Ciencias, Universidad de \\ Zaragoza, c/Pedro Cerbuna 12, 50009 Zaragoza, Spain. \\ ${ }^{2}$ Departamento de Ciencias de la Tierra, Facultad de Ciencias, Universidad de Zaragoza, c/Pedro Cerbuna No. 12, \\ 50009 Zaragoza, Spain. \\ e-mail addresses: puertola@unizar.es (E.P.P, *corresponding author); jicanudo@unizar.es (J.I.C.); Imsender@yahoo.es (L.M.S.)
}

Received: 15 December 2013 / Accepted: 18 December 2014 / Available online: 25 March 2015

\begin{abstract}
In 2011 the partial skeleton of a goniopholidid crocodylomorph was recovered in the ENDESA coal mine Mina Corta Barrabasa (Escucha Formation, lower Albian), located in the municipality of Andorra (Teruel, Spain). This new goniopholidid material is represented by abundant postcranial and fragmentary cranial bones. The study of these remains coincides with a recent description in 2013 of at least two new species of goniopholidids in the palaeontological site of Mina Santa María in Ariño (Teruel), also in the Escucha Formation. These species are Anteophthalmosuchus escuchae, Hulkepholis plotos and an undetermined goniopholidid, AR-1-3422. In the present paper, we describe the postcranial and cranial bones of the goniopholidid from Mina Corta Barrabasa and compare it with the species from Mina Santa María. For the first time, we include the taxa from the Escucha Formation in a phylogenetic analysis to establish their relationships within Goniopholididae, adding to what is known of the goniopholidid fossil assemblages from this time interval. The results indicate that the specimen from Mina Corta Barrabasa is closely related to Anteophthalmosuchus escuchae and may be the same species. Together with Hulkepholis plotos and other taxa from England and Belgium, these taxa form an endemic European clade. The Escucha Fm. goniopholidids are the youngest Eurasian members of the group and may be the youngest globally, depending on how North American taxa are eventually resolved.
\end{abstract}

Keywords: Crocodylomorpha, Goniopholididae, Iberian Range, Early Cretaceous, Iberian Peninsula

\section{Resumen}

En 2011 se recuperó parte de un esqueleto de crocodilomorfo goniofolídido en la mina de carbón Mina Corta Barrabasa (Formación Escucha, Albiense inferior). Esta mina pertenece a la compañía ENDESA, y está localizada en Andorra (Teruel, España). Este nuevo ejemplar de crocodilomorfo está representado por abundante material postcraneal y restos craneales fragmentarios. Nuestro estudio coincide con la reciente descripción en 2013 de las nuevas especies de goniofolídidos Anteophthalmosuchus escuchae y Hulkepholis plotos en la Formación Escucha (Mina Santa María en Ariño, Teruel). En este trabajo se describen los restos postcraneales y craneales del goniofolídido de Mina Corta Barrabasa y se comparan con las nuevas especies de Mina Santa María, además se propone por primera vez una codificación cladística para los taxones de la Formación Escucha. Esta información se ha incorporado a un análisis filogenético para establecer las relaciones filogenéticas de estos taxones dentro de Goniopholididae ayudando a comprender las asociaciones fósiles de los goniofolídidos dentro de este intervalo temporal. Los resultados indican que el espécimen de Mina Corta Barrabasa está estrechamente relacionado con Anteophthalmosuchus escuchae y podría pertenecer a la misma especie. Ambos taxones, junto a Hulkepholis plotos y otros taxones de Inglaterra y Bélgica, forman un clado endémico europeo. Los goniofolídidos de la Fm. Escucha son los miembros más jóvenes de Goniopholididae en Eurasia, y podrían ser los más modernos del mundo dependiendo de cómo se resuelvan finalmente la posición de los taxones norteamericanos. 


\section{Introduction}

Neosuchian remains are relatively abundant in palaeontological sites of the Spanish Mesozoic, but the diagnostic cranial material recovered is usually scarce and fragmentary. Nevertheless, in recent years the situation has changed, with the description of new taxa in the Lower Cretaceous (Buscalioni et al., 2013) and Upper Cretaceous (Puértolas et al., 2011; Puértolas-Pascual et al., 2014) providing significant phylogenetic and palaeobiogeographical results. The Lower Cretaceous is a geological range of great importance in reconstructing the radiation of advanced neosuchians and the origin of Eusuchia (Buscalioni et al., 2003; Salisbury et al., 2006; Martin and Delfino, 2010). In Europe, there is a great diversity of taxa that fall precisely within this phylogenetic position, one such group being the goniopholidids.

The vertebrate fossil record of the Early Cretaceous of Teruel (Aragón, Spain) is abundant until the Barremian (Ruiz-Omeñaca et al., 2004; Cuenca-Bescós et al., 2011), but traditionally scarce in the rest of the Early Cretaceous. In recent years there has been a breakthrough in the understanding of Albian vertebrate assemblages due to the sites found in coal mines (Canudo et al., 2004; Alcalá et al., 2012; McDonald et al., 2012; Buscalioni et al., 2013; Kirkland et al., 2013). These assemblages include the presence of crocodylomorphs.

During 2011, the research group Aragosaurus-IUCA from the Universidad de Zaragoza carried out two excavations in the Escucha Formation in the coal mine Mina Corta Barrabasa, owned by the company ENDESA. This mine is located close to the village of Andorra (Teruel) in the east of Spain (Fig. 1). Abundant fossils were recovered (corresponding to more than 200 remains) that belong to a large, disarticulated neosuchian crocodylomorph (CCB-1). On the basis of the combination of characters present in the cranial fragments, jaw, dentition and dermal armour, the crocodylomorph was preliminarily classified within Goniopholididae (PuértolasPascual et al., 2012; Puértolas-Pascual and Canudo, 2013). Almost simultaneously, other investigations were being conducted by the Fundación Conjunto Paleontológico de TeruelDinópolis and the Universidad Autónoma de Madrid in the lower Albian (Escucha Formation) of Mina Santa María (Ariño, Teruel) (Alcalá et al., 2012; Buscalioni et al., 2013), located just $10 \mathrm{~km}$ east of Mina Corta Barrabasa. In Mina Santa María, an undetermined goniopholidid and two new species of goniopholidids were described: Anteophthalmosuchus escuchae and Hulkepholis plotos. These new taxa are goniopholidids closely related with the genus Goniopholis (Buscalioni et al., 2013).

Goniopholididae is a clade of neosuchian crocodylomorphs typical of the Jurassic-Cretaceous of Laurasia. Their remains are very abundant in the fossil record of the Late Jurassic and Early Cretaceous of Western Europe (Salisbury et al., 1999; Schwarz, 2002; Schwarz-Wings et al., 2009; Andrade
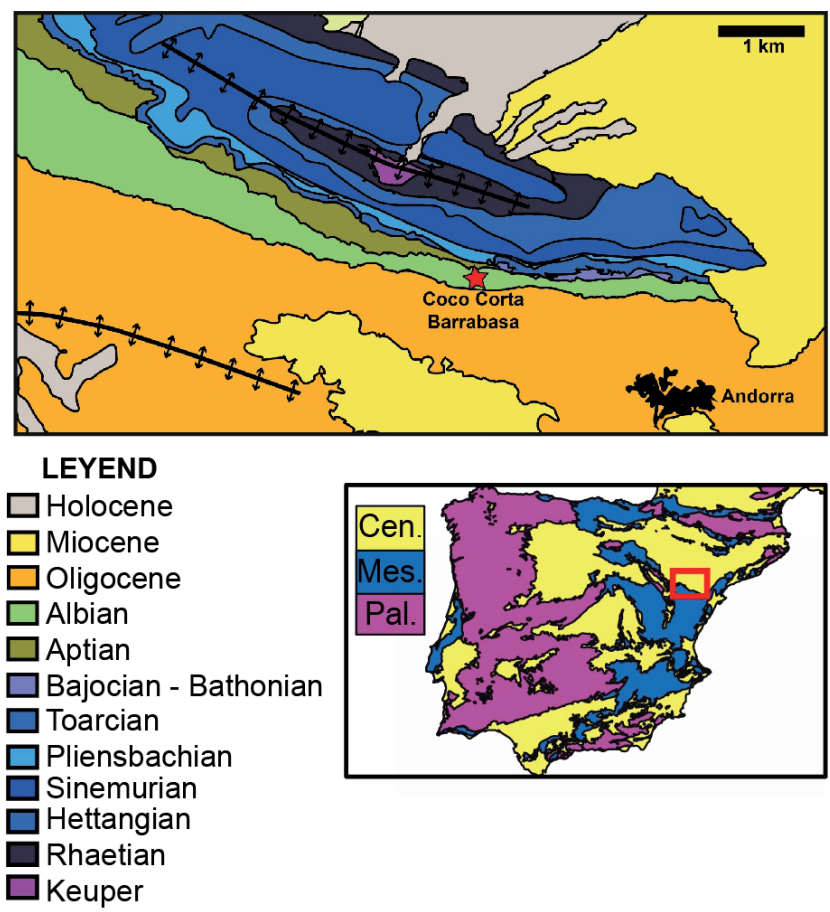

Fig. 1.- Geographical and geological location of the Coco Corta Barrabasa (CCB) palaeontological site.

and Hornung, 2011; Salisbury and Naish, 2011) and the Iberian Peninsula (Buscalioni and Sanz, 1987; Ortega et al., 1996; Canudo et al., 2010; Buscalioni et al., 2013). There are also several records of Goniopholididae in Asia and North America, but the phylogenetic relationships of most of these taxa remain unclear (Pritchard et al., 2013; Halliday et al., in press).

Since the first Goniopholis was discovered and described (Owen, 1842; Cope, 1875), this genus has been used as a "catch-all" taxon within Goniopholididae for a variety of species based on fragmentary material (Andrade et al., 2011), with as many as 19 species included within the genus (Salisbury and Naish, 2011). In the last few years, an exhaustive revision of Goniopholididae and the genus Goniopholis has been carried out (Andrade and Hornung, 2011; Andrade et al., 2011; Salisbury and Naish, 2011; Buscalioni et al., 2013). These works confirm that Goniopholididae is formed by a variety of basal taxa from Asia and North America and two derived European clades, one of which includes three species of Goniopholis and the other is composed of taxa such as Anteophthalmosuchus and Hulkepholis. The goniopholidids from Ariño and Andorra belong to the latter clade, which represents the last record of Goniopholididae in Europe, indicating a more complex scenario as regards goniopholidid diversity (Buscalioni et al., 2013).

The aim of this paper is to describe the goniopholidid from Mina Corta Barrabasa, compare it with closely related taxa and provide a phylogenetic proposal for the neosuchians described in the Escucha Formation of Teruel, including the material studied in this work. 


\section{Material}

The material studied in this paper corresponds to a single individual of a goniopholidid (CCB-1) from the palaeontological site of Coco Corta Barrabasa. Only skeletal elements corresponding to the middle and anterior region of the specimen have been identified, mainly postcranial bones, but also fragmentary cranial remains. Among the fossils identified were several fragmentary cranial bones: frontal, parietal, right postorbital, left squamosal, right prefrontal, left quadrate, left jugal, left quadratojugal, left lacrimal and several undetermined fragments; left mandible and a fragment of the right, and one isolated tooth; and postcranial bones: 2 paravertebral osteoderms from the nuchal region, 16 paravertebral osteoderms from the trunk region, 22 ventral osteoderms and 16 appendicular osteoderms; 3 cervical and 7 dorsal vertebrae; 2 cervical and 6 thoracic ribs; left coracoid, left and right ulnae, left and right radii, left and fragmentary right ulnare, left radiale, 4 metacarpals and 1 phalanx. On the basis of the large size of the bones of the skull and postcranial skeleton, and the length of the left mandible, which is almost completely preserved with a total length of about $70 \mathrm{~cm}$, we can estimate that it would have been a huge crocodylomorph that could have reached about $5 \mathrm{~m}$ in length (see Sereno et al., 2001). The material is temporarily housed at the Museo de Ciencias Naturales de la Universidad de Zaragoza (MPZ), Zaragoza (Spain). It will be transferred to the Museo Aragonés de Paleontología/Fundación Conjunto Paleontológico de TeruelDinópolis (Teruel, Spain).

Institutional abbreviations: AR, Ariño collection, housed at the Museo Aragonés de Paleontología (Fundación Conjunto Paleontológico de Teruel-Dinópolis), Teruel, Spain; $C C B$, Coco Corta Barrabasa collection; IRSNB, Institut Royal des Sciences Naturelles de Belgique, Brussels, Belgium.

Anatomical abbreviations: $A-B$, quadrate crests; alp, anterolateral process; an, angular; aop, anterior oblique process; ar, articular; cap, capitulum; cqp, cranioquadrate passage; de, dentary; diap, diapophysis; drg, distal radial groove; exo, exoccipital; fo, foramen; fr, frontal; gl fo, glenoid fossa; gl sf, glenoid surface; itf, infratemporal fenestra; j, jugal; j cr, jugal crest; la, lachimal; ns, neural spine; olf, olfactory bulbs cavity; olp, olecranon process; or, orbit; or n, orbital anterior notch; o re, external otic recess; pa, parietal; pab, palpebral scar; pfr, prefrontal; pfr pi, prefrontal pillar insertion; po, postorbital; pob, postorbital bar insertion; pre, preotic foramen; prz, prezygapophysis; q, quadrate; q bs, quadrate boss; qj, quadratojugal; qj sp, quadratojugal spine; par, parapophyses; pmp, posteromedial process; pop, posterior oblique process; poz, postzygapophysis; rdf, radius facet; rds, radiale articular surface; re pro, retroarticular process; s, sulcus; stf, supratemporal fenestra; sq, squamosal; su, surangular; su cr, surangular crest; t, tooth; tub, tuberculum; uf, ulnar facet; uhs, ulnar- humeral articular surface; unf, ulnare facet; urs, ulnar-radiohumeral articular surface.

\section{Geology and Locality}

\subsection{Geographical and geological setting}

The studied vertebrate remains were found in a former open pit coal mine called Mina Corta Barrabasa, which is located near the Andorra village in the comarca of AndorraSierra de Arcos (Teruel province, eastern Spain). This area is located in the Oliete Sub-basin within the Maestrazgo Basin, and the layer containing the bones is located at the base of the first exploitable coal seam corresponding to the Escucha Formation (Fig. 2).

\subsection{Stratigraphical and sedimentological setting}

The deposits of the Escucha Formation extend across a wide area in NE Spain. They consist of alternate sandstones and clays with layers containing coal seams and sporadic marine limestones that are found intercalated (Fig. 2). This formation is limited at the base by the Aptian limestones (Urgon Facies) corresponding to the Oliete and Villarroya de los Pinares formations and at the top by the sandy Albian deposits of the Utrillas Formation (Aguilar et al., 1971). The Escucha Formation has been divided into three members (Cervera et al., 1976), corresponding to the development of a tidally influenced delta-estuary system with different environments and related depositional sub-environments (Querol et al., 1992) (Fig. 2). The base of the Escucha Formation (Lower Member) in the Oliete Sub-basin has been dated with planktonic foraminifera as late Aptian in age by De Gea et al. (2008), and the Middle and Upper Members in this area have been dated as early to mid-Albian in age on the basis of the study of palynomorphs (Villanueva Amadoz, 2009).

The deposits containing the bones are composed of light brown to grey sandy clays that are cemented at their base, containing abundantly both ferruginous crusts and nodules. Crusts of secondary gypsum are also very common. A great quantity of non-articulated shells corresponding to indeterminate bivalves occur in the layers at the base of this bonebed, and a great accumulation of nearly complete linear leaves of conifers occurs in the grey laminated clays located at the top. Abundant remains of both carbonaceous and charcoalified wood fragments are also present in this stratigraphic level (Fig. 2).

According to Martín et al. (1986), the stratigraphic location of the studied vertebrate-rich level of Andorra would correspond to the deposits of the lower part of the Middle Member of the Escucha Formation, which include the transition between brackish swamp plain and freshwater swamp plain depositional sub-environments (Querol et al., 1992). Related deposits in the nearby area of Ariño have been dated as early Albian in age on the basis of the study of the charophytes and ostracodes preserved in them (Tibert et al., 2013). 


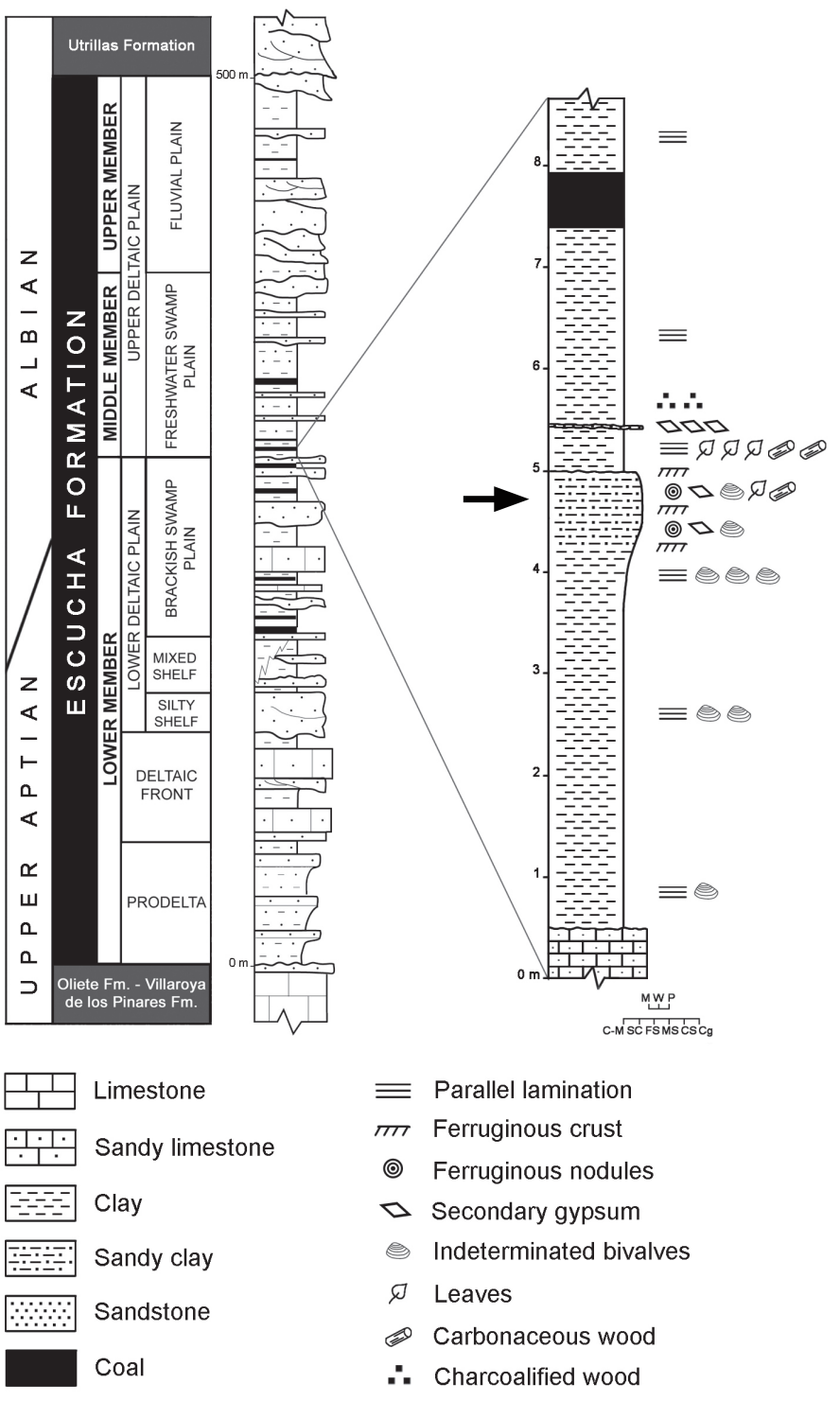

Fig. 2.- Synthetic stratigraphic section of Escucha Formation in eastern of Spain (left) (modified from Querol et al., 1992 and VillanuevaAmadoz, 2009) and detailed section of the outcrop containing studied remains (right). Position of the stratigraphic level containing bones is indicated with the black arrow.

\section{Systematic Palaeontology}

Crocodylomorpha Walker, 1970

Mesoeucrocodylia Whetstone and Whybrow, 1983

Neosuchia Benton and Clark, 1988

Goniopholididae Cope, 1875

Anteophthalmosuchus Salisbury and Naish, 2011

Type species: Anteophthalmosuchus hooleyi Salisbury and Naish, 2011

Anteophthalmosuchus escuchae Buscalioni, Alcalá, Espílez and Mampel, 2013

Holotype: AR-1/37, a partial skeleton and skull (AR-1-1097)

Anteophthalmosuchus cf. escuchae (Figs. 3, 4, 5, 6)

\section{Description}

\section{Skull}

The preserved cranial bones are scarce and disarticulated. Nevertheless, the preserved bones allow us to identify important characters of the periorbital region, skull table and occipital region.

The lateral and anterior margin of the left orbit (Fig. 3A) and the posteromedial margin of the right orbit (Fig. 3B) have been preserved. The orbits face dorsally and are subcircular in shape. Their margins are composed of the jugal laterally, lacrimal anteriorly, prefrontal medially, frontal posteromedially, and postorbital posteriorly. As in most goniopholidids, in the anterior margin of the orbit a longitudinal fossa is formed on the lacrimal-jugal contact. As in Anteophthalmosuchus, a small (but thick) rectangular suture for the palpebral bone is observed in its medial margin.

The medial and anteromedial margins of the right supratemporal fenestra have been preserved (Fig. 3B). A shallow fossa is present in its anteromedial margin. From the preserved margins we can infer that the supratemporal fossa is larger than the orbit and the supratemporal fenestra has a similar size. In contrast to AR-1-1097, the lateral margin of the parietal in the intertemporal bar is straight rather than convex. These fossae would be more square than circular.

Only the posterior and posterolateral margin of the right prefrontal have been preserved (Fig. 3B). There is no prefrontal-lacrimal crest medial to the orbit; even its dorsal surface is slightly depressed in this region. The lateral margin corresponds to the suture with the unpreserved palpebral, taking up part of the anteromedial and medial borders of the orbit. Only the lateromedial lamina of the descending process of the prefrontal pillar has been preserved. This lateromedial lamina is well developed and forms a big concavity for the olfactory bulbs.

The right frontal is almost complete (Fig. 3B) and only lacks the anteriormost region, so sutures with the nasals cannot be determined. Its dorsal surface is flat and well ornamented with circular pits. There is no transverse frontal crest or hump between the orbits. The anterior process tapers anteriorly between the prefrontals. The medial margin corresponds to the suture with the unpreserved left frontal, so they could be unfused along the midline of the skull table. The lateral margin corresponds to the suture with the unpreserved palpebral and postorbital; the frontal can thus be seen to take up part of the medial and posteromedial margin of the orbit.

Part of the right parietal has been preserved (Fig. 3B). This region corresponds to the right half of the intertemporal bar. The left parietal is not preserved coinciding with the midline suture, suggesting that the parietals would not be completely fused. Its dorsal surface is flat and covered with circular pits. The frontoparietal suture is located in the middle of the intertemporal bar, and it is straight, crenulated and enters the supratemporal fenestra on its anteromedial margin. 


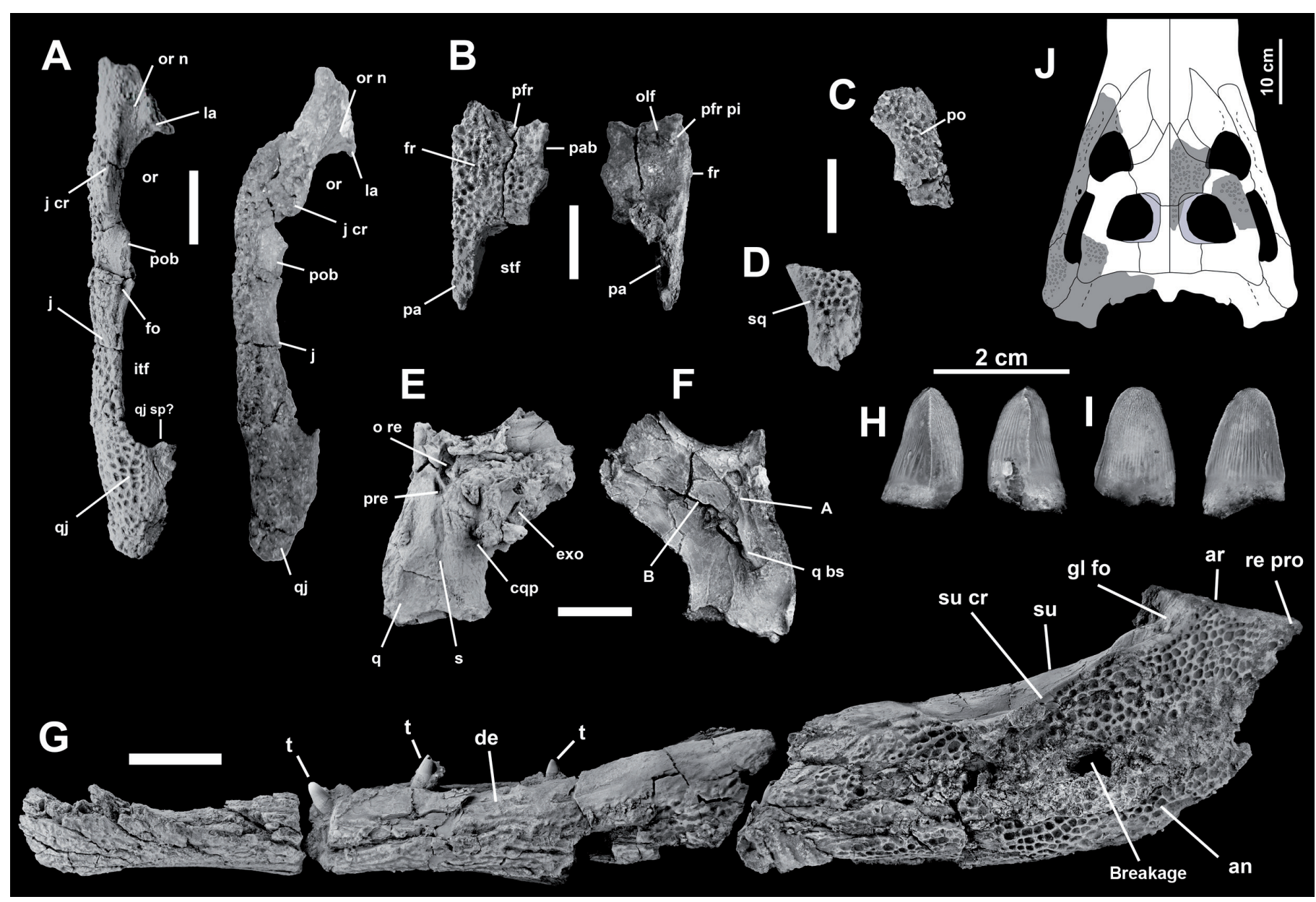

Fig. 3.- Cranial bones of CCB-1: A, left quadratojugal, jugal and lachrymal in dorsal view; B, right frontal and parietal in dorsal view; $\mathrm{C}$, right postorbital in dorsal view; D, left squamosal in dorsal view; E, left quadrate in dorsal view; F, left quadrate in ventral view; G, left mandible in lateral view; $\mathrm{H}$, isolated tooth in anterior and posterior views; I, isolated tooth in labial and lingual views; J, reconstruction of the skull CCB-1 in dorsal view, the preserved bones are marked in gray. Unnumbered scale bar $=5 \mathrm{~cm}$.

The presence of fused parietals or frontals is quite difficult to ascertain in CCB-1; this is because only the right half of these bones has been preserved, the bones being broken at the midline or in the suture zone. This could either be because they were not actually fused, or because although the bones were fused, they preserved the old suture zone as a weakness plane tending to break.

A fragment of the right postorbital has also been preserved (Fig. 3C). It corresponds to the lateral bar of the supratemporal fenestra. Its anterior region is broken, and the postorbital bar is not preserved. Nevertheless, it allows us to interpret the morphology of the lateral margin of the supratemporal fenestra and skull table. As in AR-1-1097, the lateral margin of the skull table is straight rather than curved and the lateral bars of the skull table seem to be slightly divergent posteriorly.

The left jugal has been preserved (Fig. 3A) and is almost complete, lacking only the anterior tip. The postorbital bar is not preserved. The jugal is long and lateromedially compressed with a subcircular to subpolygonal cross-section. Most of the dorsal and lateral surface of the jugal is ornamented with circular pits with the exception of the smooth dorsal area next to the postorbital bar insertion. In the dorsal surface of the jugal there is a foramen located posteriorly to the postorbital bar. The anterior process of the jugal is short and extends in front of the anterior orbital groove. The jugal forms a strongly elevated crest on the lateral margin of the orbit. In lateral view the ventral surface of the jugal has a longitudinal sulcus between its anterior and posterior ramus. Below this sulcus the jugal is ventrally arched.

Most of the left quadratojugal has been preserved (Fig. $3 \mathrm{~A})$. The lateral surface of the quadratojugal is strongly ornamented with circular pits, with the exception of the quadratojugal-quadrate contact, which is smooth. The quadratojugal forms the entire posterior margin of the infratemporal fenestra. The anterodorsal extension of the quadratojugal is partially broken, but it seems to reach the dorsal angle of the infratemporal fenestra. There seems to be no quadratojugal spine in the posterior region of the infratemporal fenestra, but this could be due to preservation factors.

The left quadrate is fully preserved (Fig. 3E-F). Its entire surface is smooth, without ornamentation. The ventral margin of the otic region has been preserved and is formed by the quadrate. Posterolaterally to the otic aperture there is a 
preotic foramen. As in AR-1-1097, the dorsal surface of the quadrate has two sulci separated by a convex surface. One sulcus begins at the preotic foramen and runs posterolaterally. The second corresponds to the cranioquadrate passage and begins at the otic aperture and runs posteromedially, with the exoccipital forming its dorsomedial margin. The foramen aërum is not observed in the dorsal surface, but this could be due to preservation factors. The main body of the quadrate has a low inclination, being almost aligned with the horizontal plane. The two quadrate hemicondyles are subequal in size and small, the medial hemicondyle is medioventrally twisted. Ventrally (Fig. 3F), the quadrate has two crests that correspond to muscle scar A and B of Iordansky (1973). Crest $\mathrm{B}$ is much stronger than crest $\mathrm{A}$, and they converge posteriorly to form a well-marked bump. Medially to crest B, the surface of the quadrate is strongly concave. Dorsomedially to the quadrate, the paroccipital process of the exoccipital has been partially preserved.

\section{Mandible}

The left mandible and part of the right mandible have been preserved. The left mandible is almost complete but is broken into three pieces (Fig. 3G), its total length being approximately $70 \mathrm{~cm}$. The entire lateral surface of the angular and surangular is strongly ornamented by circular pits. On the lateral surface of the dentary, longitudinal grooves are also present, being very similar to AR-1-1097. The mandible presents an evident festooning in lateral view with two dorsal projections on the anterior and middle dorsal margin of the dentary. Only three teeth from the middle-posterior region of the dentary have been preserved. Most of the alveolar margin is partially broken, ruling out a correct interpretation of the teeth size and configuration. There is no mandibular fenestra.

As in AR-1-1097, the angular has a gently curved ventral profile below the glenoid fossa. The angle between the posterior and ventral margins is about $120^{\circ}$. The angular has a horizontal suture with the surangular in the anterior and middle section. Towards the back of the posterior section, the angular rises up to reach the ventral posterior tip of the retroarticular process.

The posterior part of the surangular extends to reach the lateral posterior tip of the retroarticular process. On its dorsolateral margin, the surangular has a well-marked longitudinal crest that runs from the glenoid fossa as far as its anterior region; this is also present in AR-1-1097, but less marked. In the middle region of the surangular, this crest is strongly marked and dorsolaterally elevated, forming a longitudinal fossa between the crest and the dorsal margin of the surangular. The fossa has a smooth surface and faces dorsolaterally. The lateral surangular-dentary contact is formed by a forked anterior process with its dorsal ramus slightly longer than the ventral ramus.

The glenoid fossa faces anterodorsally, is wider than long and has a well-developed posterior margin. Posterior to the glenoid fossa, there is a long and almost horizontal retroarticular process very similar to that in AR-1-1097. The attachment surface for the adductor muscles is partially broken, but its general morphology can be observed. The sutural relationships with the articular are obscured. The dentary symphysis is short. The splenial is robust and reaches half way along the symphysis.

\section{Dentition}

Only four teeth have been preserved. One was recovered isolated (Fig. 3H-I), and the other three are from the middleposterior region of the left dentary. All the teeth have a similar morphology and are almost equal to that in AR-1-1097; they are conical, relatively short and robust, with the labial surface more convex than the lingual surface. The posteriormost preserved tooth of the dentary is slightly shorter and more slender. Two carinae are well developed in the anterior and posterior surfaces of the teeth; these carinae are basoapically straight with the exception of a slight undulation in the apical-most region. The teeth have strong ornamentation composed of numerous, well-defined baso-apical, longitudinal ridges. These ridges present a strong anastomosis in the middle-apical region, crossing the carinae developing falseziphodont crenulations.

\section{Axial skeleton}

There are no preserved vertebrae in articulation, making it difficult to assign them correctly within the vertebral series, but we have nonetheless tried to make an approximate assignment based on the morphology for each of the vertebrae preserved. At least three cervical vertebrae (probably the $5^{\text {th }}$, $7^{\text {th }}$ and $8^{\text {th }}$ based on the shape and position of the diapophyses and parapophyses) and six dorsal vertebrae (the first five from the thoracic region and one from the lumbar region) have been preserved partially complete (Fig. 4). Furthermore, there are many undetermined vertebral fragments. All the preserved vertebrae are clearly amphicoelous, with the centrum circular, ventrally concave and as high as broad.

All the cervical vertebrae have the neural spine broken off. The cervical vertebrae develop hypapophyses with a slight sagittal crest in the ventral region of the centrum; this crest is more pronounced anteriorly. The anteriormost preserved cervical vertebra (Fig. 4F-G) has well-developed elliptical parapophyses on the lateroventral margins of the centrum, close to the anterior articulation facet. These parapophyses are more dorsally placed and in the middle of the lateral margin of the centrum in the posterior cervical vertebrae. The diapophyses of the cervical vertebrae have an elliptical section. These diapophyses show a gradual evolution from the more anterior cervical vertebrae to the more posterior cervical vertebrae, from being shorter, ventrally projected and in a more anterior position, to longer, more laterally projected and in a posterior position. The last cervical vertebra has the diapophyses later- 


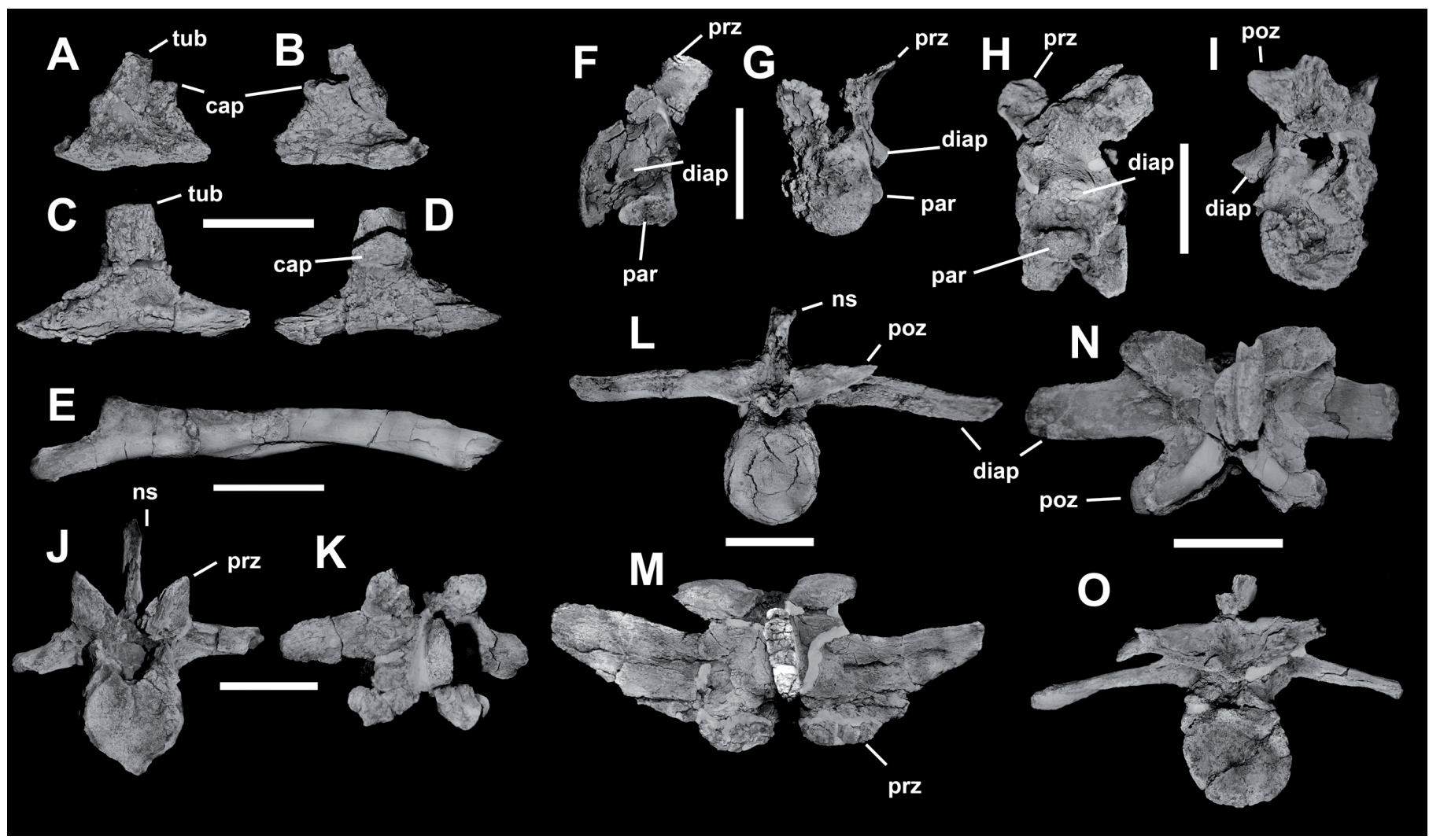

Fig. 4.- Axial bones of CCB-1: A-B, fourth right cervical rib in lateral and medial views respectively; C-D, fifth left cervical rib in lateral and medial views respectively; E, right dorsal rib in ventromedial view; F-G, fifth cervical vertebra in lateral and posterior views respectively; H-I, seventh cervical vertebra in lateral and posterior views respectively; J-K, first dorsal vertebra in anterior and dorsal views respectively; L-M, dorsal vertebra in posterior and dorsal views respectively; N-O, lumbar vertebra in dorsal and posterior views respectively. Scale bar $=5 \mathrm{~cm}$.

ally projected, expanded mediolaterally and twisted from the horizontal plane with their elliptical section posteroventrally oriented. The prezygapophyses and postzygapophyses are dorsally oriented with a significant vertical component.

The first thoracic dorsal vertebra (Fig. 4J-K) is very similar to the last cervical vertebra. It can be distinguished by its slightly longer diapophyses, which are dorsally placed with respect to the neural canal, or the parapophyses, which are less marked, dorsally placed and closer to the neurocentral suture (Mook, 1921; Wu et al., 1996; Nascimento and Zaher, 2010). In the first dorsal vertebra there is still a crest in the ventral region of the centrum, whereas in the other preserved dorsal vertebrae this crest does not exist. The postzygapophyses of this vertebra are symmetrically broken and have a fault in their posterolateral tip. This strange symmetric morphology in the two postzygapophyses is probably a taphonomic quirk.

The other thoracic vertebrae (Fig. 4L-O) are characterized by longer, horizontal and flat diapophyses. In these vertebrae the parapophyses are not located in the vertebral centrum and they are located dorsally between the prezygapophyses and the diapophyses, moving laterally toward the lateral tip of the diapophyses in the posterior thoracic region. In the thoracic vertebrae, the prezygapophyses and postzygapophyses are oriented almost in the horizontal plane, being quite planar.
A dorsal vertebra from the lumbar region has also been preserved (Fig. 4N-O). This vertebra is also characterized by the presence of long and flat diapophyses almost in the horizontal plane, but it is slightly ventrally inclined. The lumbar vertebra is also distinguished by the absence of parapophyses because there are no ribs in this region of the body. Furthermore, the prezygapophyses and postzygapophyses are more dorsally oriented than in the thoracic vertebrae.

Two cervical ribs and several fragmentary dorsal ribs have been preserved (Fig. 4A-E). The two cervical ribs have the parapophyseal articulation (capitular process or capitulum) and the diapophyseal articulation (tubercular process or tuberculum), and a horizontal shaft that extends both anterior to and posterior to the articular processes.

The anteriormost preserved cervical rib probably corresponds to the fourth right cervical rib (Fig. 4A-B). Its capitulum is slightly larger and more anteriorly placed than the tuberculum. Furthermore, the anterior process of the shaft is shorter than the posterior process. The posterior process is not fully preserved but it has a dorsomedial facet for the reception of the anterior extension of the fifth rib.

The other cervical rib probably corresponds to the fifth left cervical rib (Fig. 4C-D). In this case, the capitulum is only slightly more anteriorly placed with respect to the tuberculum, and they are almost parallel. The capitulum is clearly 
larger than the tuberculum. The posterior and anterior processes of the horizontal shaft are subequal in size.

The dorsal ribs are long and greatly curved. Only two dorsal ribs preserve the articulation facets. These correspond to the fourth, fifth or sixth dorsal ribs. In these ribs the articulation facet only has a capitular process; the tubercular facets are at the end of the shaft without distinct processes. The best-preserved dorsal rib has a prominent anterior crest for muscle attachment (Fig. 4E).

\section{Dermal skeleton}

The most abundant remains of CCB-1 are osteoderms. Paravertebral, ventral, appendicular and nuchal dorsolateral osteoderms have been identified. The dermal armour is very similar to that of goniopholidids such as Goniopholis simus from the Berriasian of England and Germany, Anteophthalmosuchus hooleyi from the Valanginian of England, the unnamed Dollo's goniopholidid from the Barremian-Aptian of Belgium, Goniopholis baryglyphaeus from the Kimmeridgian of Portugal, and Sunosuchus junggarensis from the Late Jurassic of China (Wu et al., 1996; Salisbury and Frey, 2001; Schwarz, 2002; Salisbury and Naish, 2011).

The paravertebral or dorsal osteoderms (Fig. 5A-E) form two sagittal rows and they are rectangular in shape and twice as wide as long, being longer in the mediolateral direction. The medial suture between osteoderms in each transverse row is difficult to see in most osteoderms due to conservation factors. These osteoderms are narrower in the anterior region of the trunk (Fig. 5A) and wider in the middle region of the trunk (Fig. 5B-E). The dorsal surface is fully covered by circular pits, with the exception of the anterior margin, which is smooth to allow for the overlapping articulation with the anterior osteoderm. The lateral margins are curved and ventrally projected, and the angle at which they are inclined ventrally with respect to adjacent osteoderms varies throughout the dermal armour. In the anteriormost osteoderms this inclination is almost $0^{\circ}$, but it increases progressively to about $90^{\circ}$ in the lumbar region. This feature, combined with the variable width of the osteoderms, allows the dorsal osteoderms to be placed in their approximate anatomical position within the dermal armour. In contrast to other goniopholidids, there is no anteroposterior crest on the laterodorsal surface of the osteoderms. All the dorsal osteoderms possess an anterolateral spine-like articular process, which is set in a shallow groove in the ventrolateral surface of the anterior osteoderm. This spine is conical and dorsoventrally compressed.

The dorsolateral osteoderms of the neck region (Fig. 5L) are clearly different from the other dorsal osteoderms. These osteoderms are smaller, ellipsoidal in shape, ornamented with circular pits and with an anteroposterior ridge on the dorsal surface. There are other osteoderms similar in shape; these are from the limbs (Fig. 5M), but lack the ridge on the dorsal surface (Wu et al., 1996).
The ventral or gastral osteoderms form a dermal armour as a mosaic of polygonal osteoderms attached to each other and with circular pits in a flat or very gently convex ventral surface. Most of these osteoderms are hexagons (Fig. 5F-G) with fairly regular edges, although some of them are also square (Fig. 5H), rectangular or rounded in shape. Most of the polygonal osteoderms present articular facets on all sides, being representatives of the more medial ventral osteoderms (Fig. 5F-H), which are completely surrounded by other osteoderms. Other ventral osteoderms lack the articulation facet on one side, being part of one of the lateral margins of the ventral dermal armour (Fig. 5I). In a few ventral osteoderms, smooth overlapping facets are observed along one margin of their outer surfaces (Fig. 5J-K); these osteoderms are from the region between the neck and trunk in other goniopholidids such as Sunosuchus (Wu et al., 1996).

\section{Appendicular skeleton}

Appendicular bones have only been preserved from the anterior region of the body. These bones correspond to part of the pectoral girdle, forelimbs, carpus, metacarpus and manual phalanges (Fig. 6).

The pectoral girdle is represented by the left coracoid (Fig. 6A-B) and part of the right coracoid blade; the scapulae have not been preserved. The coracoid possesses an enlarged dorsolateral articular region that tapers to a cylindrical middle region, to finish with a dorsoventrally flattened and anteroposteriorly expanded ventromedial blade. Its lateral or external surface is very convex, while the medial or internal surface is concave. The coracoid foramen is clearly visible in lateral and medial views, and is placed anterior to the glenoid fossa, in the dorsolateral region almost reaching the scapulocoracoid articulation, approximately in the middle of the dorsal expansion of the coracoid. The glenoid surface and the posterior margin of the coracoid blade are partially broken. The anterior margin of the coracoid blade is complete and seems to be more flared than the posterior margin. The coracoid is shorter than the ulna and subequal in length to the radius.

The preserved bones of the forelimbs are both radii and ulnae (Fig. 6C-F); the humeri have not been preserved. The left ulna (Fig. 6C-D) is the better preserved, but there is a medial taphonomic collapse in the shaft close to the proximal articulation (Fig. 6C), and the distal articulation is slightly worn. The distal end is better preserved in the right ulna. The ulna is clearly longer than the radius, with a total length of about $22 \mathrm{~cm}$. The lateral shape of the ulna is slightly sigmoid and twisted, with the proximal end pointing anteriorly and the distal end pointing posteromedially. Along the shaft there is a transition from an elliptic cross-section in the proximal region to a subcircular cross-section in the distal region. The shaft expands anteroposteriorly and mediolaterally at its proximal end, which is almost twice the size of the midshaft. The proximal articular surface has a triangular profile and comprises a 


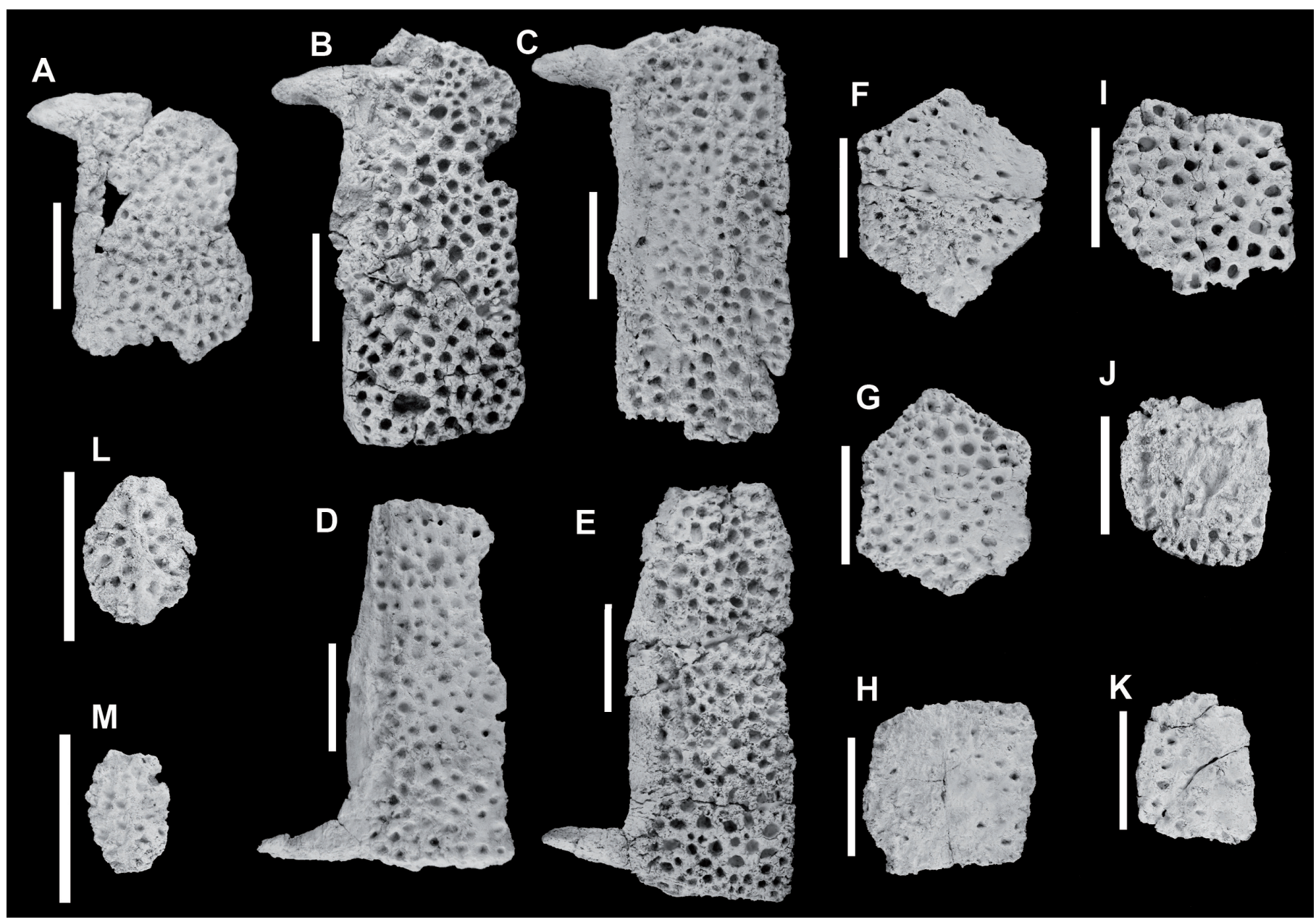

Fig. 5.- Osteoderms of CCB-1: A-E, dorsal osteoderms; F-K, ventral osteoderms; L, nuchal osteoderm; M, appendicular osteoderm. Scale bar $=5 \mathrm{~cm}$.

convex and rounded area that separates two slightly concave articulations, the ulnar-humeral articular surface (located medially) and the ulnar-radiohumeral articular surface (located laterally). The olecranon process is partially eroded or is not very prominent. The distal articulation is clearly narrower than the proximal articulation, with approximately the same width as the midshaft. The distal articulation is composed of three processes: the anterolateral process, the anterior oblique process and the posterior oblique process. All these processes are visible in both ulnae but are slightly obscured by erosion.

The left radius is better preserved (Fig. 6E-F), but the distal articulation is more complete in the right radius. The radius is shorter than the ulna, with a total length of $18.5 \mathrm{~cm}$. The radius is composed of a cylindrical and straight shaft with its distal and proximal ends slightly expanded. There are no clear tubercles or ridges on the shaft surface, but this could be due to preservation factors. The proximal articulation has a subcircular outline and is concave for the articulation with the humerus. The ulnar facet of the proximal articulation is almost straight and it separates a well-developed anterolateral process and a less-marked posteromedial process. At the distal end of the radius there is a deep groove where the ulna fits. Medial to this groove there is a ventromedially expanded process, which forms the radiale articular surface.

Only the radiale and ulnare of the left carpus have been preserved (Fig. 6G-J). Both bones are relatively short and very robust, with a length only slightly greater than their maximum width. The radiale (Fig. 6I-J) is 1.5 times longer than the ulnare (Fig. 6G-H), and is expanded at its ends, being widest in its proximal region. Its proximal articular surface has a medial and anteroposteriorly directed concavity for the insertion of the radius. Medial to this concavity there is a lateral process that is dorsally expanded. In the lateral margin of the proximal region there are two facets for the contact with the ulna and the ulnare. In posterior view there is a depression close to the proximal region that reaches the midshaft. The distal articular region of the radiale is partially broken. The midshaft is subcircular in cross-section.

The ulnare (Fig. 6G-H) is less well preserved. The shaft of the ulnare is relatively shorter than that of the radiale (about $73 \%$ of its length), and lacks any dorsally expanded process. The midshaft is subcircular in cross-section. The proximal articulation surface is subtriangular in cross-section, but the tip of the proximal facet for the radiale is partially broken. The 


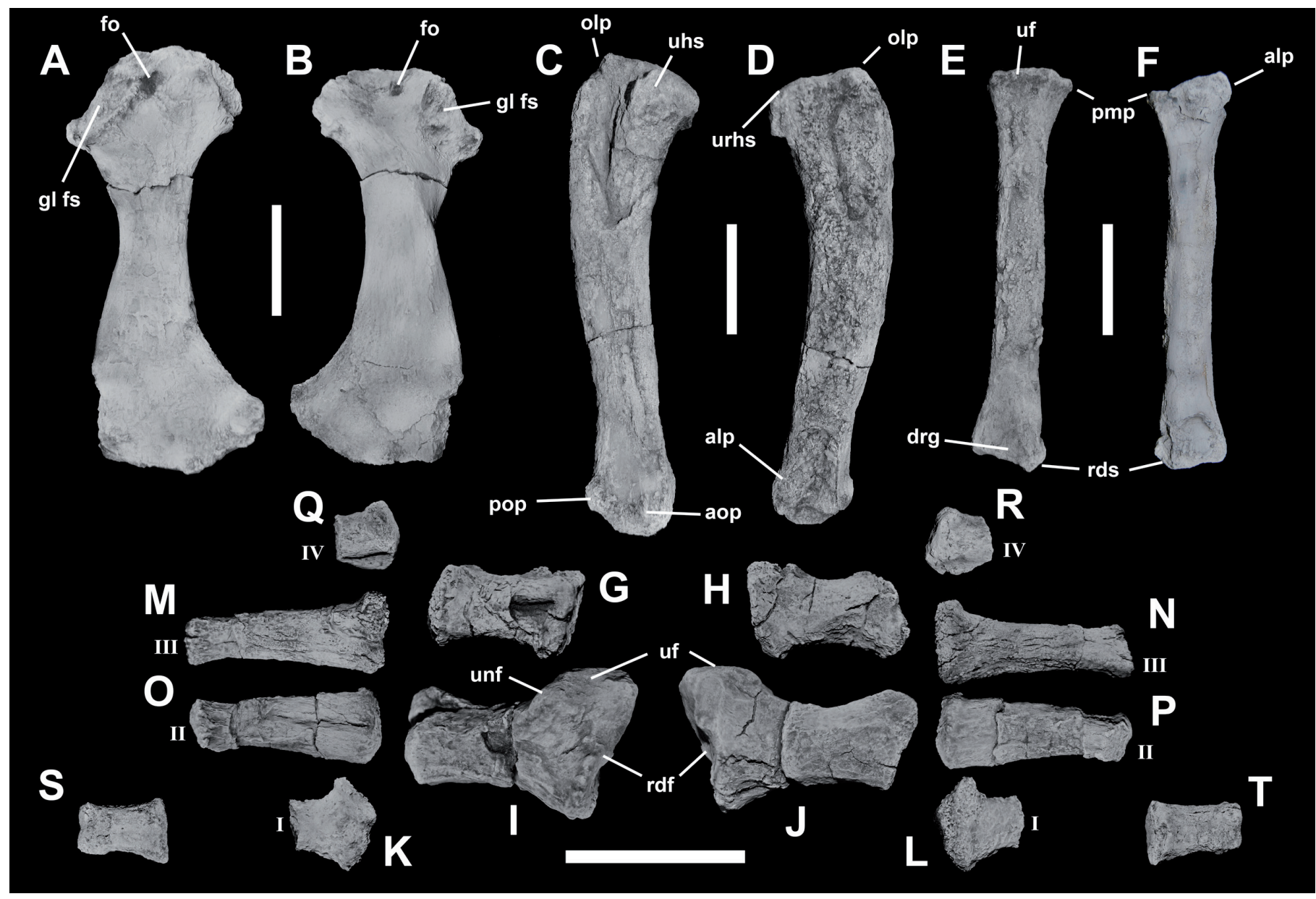

Fig. 6.- Appendicular bones of CCB-1: A-B, left coracoid in medial and lateral views respectively; C-D, left ulna in medial and lateral views respectively; E-F, left radius in posterior and anterior views respectively; G-H, left ulnare in posterior and anterior views respectively; I-J, left radiale in posterior and anterior views respectively; K-L, proximal region of left metacarpal I in posterior and anterior views respectively; $\mathrm{M}-\mathrm{N}$, left metacarpal III in posterior and anterior views respectively; O-P, left metacarpal II in posterior and anterior views respectively; Q-R, proximal region of left metacarpal IV in posterior and anterior views respectively; S-T, phalanx in posterior and anterior views respectively. Scale bar $=5 \mathrm{~cm}$.

distal articulation surface is elliptical in cross-section, and the distal facet for the radiale is also broken.

At least five elements from the manus have been identified (Fig. 6K-T); other fragmentary remains could also be from the manus, but we have not been able to identify them. When the metacarpals and phalanges are disarticulated and fragmentary, it is generally difficult to assign them correctly.

One phalanx, two almost complete metacarpals and the proximal articulation of two others have been preserved. The metacarpals (Fig. 6K-R) are subequal in length to the radiale. In view of the shape and orientation of the proximal articular facets of the preserved metacarpals, we have tentatively classified them as metacarpals I, II, III and IV of the left manus. The proximal region of metacarpal $I$ is the widest of the preserved metacarpals, and its proximal articular surface is strongly convex. The proximal articulation region of metacarpals I, II and III is flattened and mediolaterally expanded, with more symmetrical expansion in I and II, and more lateral expansion in III. The proximal end of IV is less mediolaterally expanded and more globular.
The phalanx (Fig. 6S-T) is short, robust and half the total length of the longest metacarpals. The phalanx shows the typical morphology within Crocodylomorpha and among most reptiles, with a distal region formed by two rounded condyles with a circular depression lateral and medial to the articular surface. Its proximal region is more expanded dorsally, and it is concave and subtriangular in cross-section.

\section{Phylogenetic analysis}

\subsection{Methods}

To assess its phylogenetical relations within Goniopholididae, CCB-1 from Mina Corta Barrabasa (Andorra) was included in the dataset of Andrade et al. (2011). As well as CCB-1, the goniopholidids A. escuchae (AR-1-1097) and $H$. plotos (AR-1-2045) from Mina Santa María (Ariño) were for the first time included in a cladistic analysis to test their phylogenetic relationships with CCB-1 and Goniopholididae (Appendix 1). We performed two different analyses, one tak- 
ing into account CCB-1 and AR-1-1097 as different taxa (Fig. $7 \mathrm{~A}$ ), and another combining the data from CCB-1 and AR-11097 within the same taxon, creating a composite terminal, Anteophthalmosuchus escuchae (AR-1-1097 + CCB-1) (Fig. 7B). We have not included the indeterminate goniopholidid AR-1-3422 from Mina Santa María (Buscalioni et al., 2013) because we have not been able to encode it firsthand.

All the aforementioned changes resulted in a dataset of 107 OTUs (operational taxonomic units) for the first analysis and 106 OTUs for the second, which have been coded for a total of 487 craniodental and postcranial characters. The taxon Gracilisuchus has been used as the outgroup taxon.

In TNT v1.1 (Willi Hennig Society Edition; Goloboff et al., 2008), tree-space was searched using a heuristic search algorithm (traditional search method) with tree-bisectionreconnection branch swapping and 1000 random addition replicates holding 10 most parsimonious trees for each replicate. All characters were equally weighted and multistate characters were unordered, but 24 of them were treated as ordered (see Supporting Information File S1 of Andrade et al., 2011). Bremer supports and bootstrap frequencies (1000 bootstrap replicates searched) were used to assess the robustness of the nodes.

\subsection{Results}

The first analysis resulted in sets of four equally parsimonious cladograms of 2212 steps (ensemble consistency index, $\mathrm{CI}=0.292$; ensemble retention index, $\mathrm{RI}=0.765$; rescaled consistency index, $\mathrm{RC}=0.223$ ). The second analysis resulted in sets of four equally parsimonious cladograms of 2208 steps (CI, RI, RC have the same values as in the first analysis).

These results, the bootstrap frequencies and the Bremer supports (decay index) have been summarized in the strict consensus tree (Fig. 7). The strict consensus topologies from each search procedure are almost identical to the strict consensus tree reported by Andrade et al. (2011). In both analyses, the only differences with respect to Andrade et al. (2011) are within Goniopholididae. There is a polytomy between $S$. junggarensis, Eutretauranosuchus and the clade comprising S. thailandicus + S. miaoi, while in the analysis by Andrade et al. (2011) the clade formed by Eutretauranosuchus $+S$. junggarensis is the sister clade of the clade formed by $S$. thailandicus $+S$. miaoi. Other differences are related to the position of the new taxa included in the analysis. $H$. willetti forms a polytomy with $H$. plotos, and A. escuchae + CCB-1 are the sister taxa of the clade formed by A. hooleyi + Dollo's goniopholidid.

In the two different analyses, which take CCB-1 and AR1-1097 either as different taxa (Fig. 7A) or as a composite taxon (Fig. 7B), the unambiguous synapomorphies of each node are exactly the same, with the exception of the node that affects these taxa directly (Node 6). The only results that vary slightly in each analysis are the Bremer and bootstrap values of some nodes.
Goniopholididae (Node 1) is a reasonably well-supported node (Bremer $=3$; but bootstrap $<50 \%$ ) diagnosed by the presence of the following unambiguous synapomorphies: ventralmost neurovascular foramina high in posterior region of maxilla and very distant to the alveoli; presence of lateral fossae next to the alveolar margin; presence of a maxillary depression next to the maxilla-jugal contact; frontoparietal suture medially placed to the dorsal end of postorbital bars or slightly anterior; anterior process of palatines short, with length subequal to width.

The clade composed of Goniopholis + Anteophthalmosuchus + Hulkepholis $($ Node 2$)$ lacks strong support $($ Bremer $=$ 1 ; bootstrap $<50 \%$ ) and is defined by only three unambiguous synapomorphies: anterior border of maxillary depressions well-defined; supratemporal fossae square to subrectangular; presence of two to five small neurovascular foramina, usually ventrally oriented, in the anterior ramus of jugal.

Goniopholis (Node 3) is only slightly supported (Bremer $=1$; bootstrap $\approx 70 \%$ ) and is diagnosed by the presence of only two unambiguous synapomorphies: anteriormost border of anterior process of frontal truncated; frontal participation in primary medial border of orbit very restricted or even excluded.

The clade composed of Anteophthalmosuchus + Hulkepholis (Node 4) is one of the best-supported nodes within Goniopholididae (Bremer $=6$; bootstrap $\approx 60 \%$ ) and is defined by the following unambiguous synapomorphies: presence of a long and robust anterolateral process on the postorbital; absent prefrontal-lacrimal crest dorsal to orbit; absent transverse frontal crest anteromedial to orbits, also shared with Amphicotylus lucasii; lateral processes of frontal arched laterodorsally with palpebral and postorbital curved dorsally, also shared with Kansajsuchus extensus; medial surface of frontal continuous from anterior margin to posterior end; jugal cross-section subcircular to subpolygonal; ventral margin of anterior jugal ramus level with the ventral margin of posterior ramus; anterior process of palatines longer than wide.

The clade formed by Anteophthalmosuchus (Node 5) is well supported (Bremer $=2$; bootstrap $\approx 60 \%$ ) and is defined by the following unambiguous synapomorphies: orbits with a strong dorsal component; anterior ramus of jugal below orbit forming a narrow band of bone; palpebrals small and robust; rectangular palpebrals.

The clade formed by A. escuchae (AR-1-1097) and CCB1 (Node 6) is also one of the best-supported nodes within Goniopholididae $($ Bremer $=3$; bootstrap $=85 \%$ ) and is defined by the following unambiguous synapomorphies: pits well represented on the skull with grooves usually present on maxillo-jugal suture and dentary; frontals paired (uncertain character, see Description section); temporal bars oblique and anteriorly convergent with trapezoidal outline; presence of a robust surangular crest on the lateral surface of the mandible.

The clade composed of A. hooleyi and Dollo's goniopholidid (Node 7) is very well supported (Bremer $=2$; bootstrap $\approx$ $90 \%$ ) and is defined by the following unambiguous synapo- 


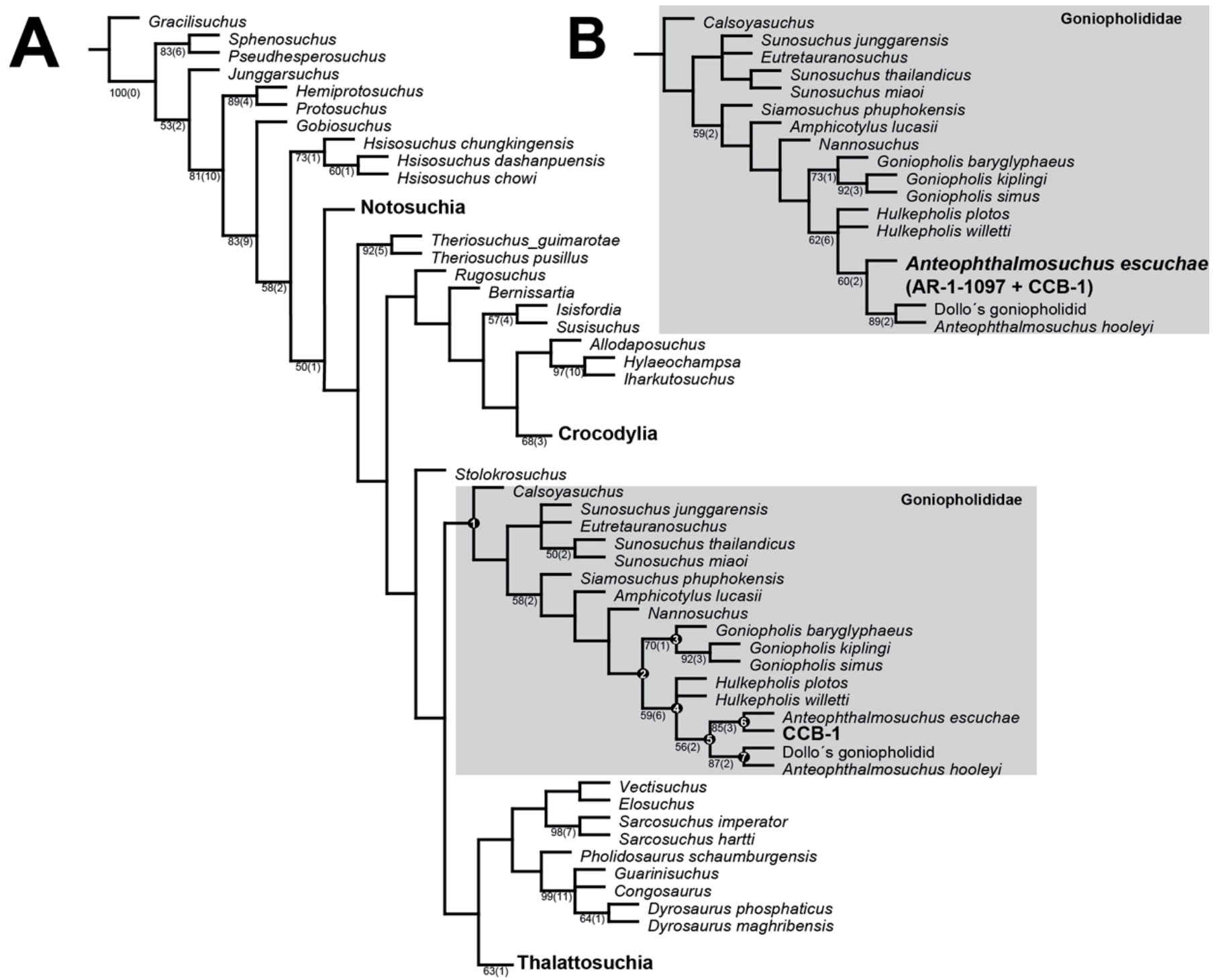

Fig. 7.- Phylogenetic relationships of CCB-1 (see text and Appendix 1 for details and statistics). A, strict consensus tree taking into account CCB1 and AR-1-1097 as different taxa; B, strict consensus tree of the node Goniopholididae with the composite terminal Anteophthalmosuchus escuchae (AR-1-1097 + CCB-1). Numbers of each node indicate the bootstrap frequencies over $50 \%$ and in parentheses is the Bremer support (decay index) as number of extra steps required before the clade is lost. The circled numbers are node 1 (Goniopholididae), node 2 (Goniopholis + Anteophthalmosuchus + Hulkepholis), node 3 (Goniopholis), node 4 (Anteophthalmosuchus + Hulkepholis), node 5 (Anteophthalmosuchus) and node 6 (AR-1-1097 + CCB-1).

morphies: supratemporal fossae square to subrectangular; very long prefrontals; lateral margins of skull table slightly convex laterally.

If we take $A$. escuchae (AR-1-1097) and CCB-1 to be different taxa in the analysis (Fig. 7A), AR-1-1097 is characterized by the following unambiguous synapomorphies: retroarticular process posterodorsally oriented; tip of retroarticular process in a more dorsal plane than the glenoid fossa. By contrast, CCB-1 is characterized by the following unambiguous synapomorphy: medial borders of supratemporal fossae straight and parallel.

Taking the composite taxon (Fig. 7B), Anteophthalmosuchus escuchae (AR-1-1097 + CCB-1) is characterized by the following unambiguous synapomorphies: pits well represented on the skull with grooves usually present on maxillo-jugal suture and dentary; absence of maxillary depression; long lachrymal; frontals paired, not fused (uncertain character, see Description section); unfused parietals (same problematic as with frontal); skull table trapezoidal with lateral margins anteriorly convergent; wide and fan-shaped palatine process; anterior face of palatine process invaginated by a maxillary wedge; maxillo-palatine suture with heart-shaped profile; robust crest on the lateral surface of surangular; ellipsoid or spoon-shaped retroarticular process.

We performed an alternative analysis including the codes of the additional taxa "Goniopholis" phuwiangensis and Denazinosuchus proposed by Andrade et al. (2011). Whether CCB-1 and AR-1-1097 were taken as different taxa or as a composite taxon, this analysis resulted in an increase to 24 equally parsimonious cladograms and two more evolutionary 
steps with scores identical to the core analysis. The presence of the fragmentary taxon "G." phuwiangensis creates a polytomy between Sunosuchus, Eutretauranosuchus and "G." phuwiangensis. The addition of Denazinosuchus produces the collapse of the basal node of Pholidosauridae. Furthermore, Denazinosuchus is positioned as a derived goniopholidid, as sister taxon of Amphicotylus and both together as the sister clade of the genus Goniopholis. In order to improve the resolution of the consensus tree, we performed a pruned tree analysis with TNT v1.1 to determine which taxa may be deleted, the fragmentary "Goniopholis" phuwiangensis proving to be the most unstable taxon. The putative goniopholidid Denazinosuchus is a controversial taxon whose phylogenetic position is still unclear (Wiman, 1932; Lucas et al., 2003, 2006; Andrade et al., 2011; Allen, 2012a; 2012b; Bremer and Kear, 2013; Irmis et al., 2013; Pritchard et al., 2013), and it should be studied in depth before being included in a cladistic analysis. The inclusion of "G." phuwiangensis and Denazinosuchus therefore does not substantially change the final indexes, but increases the number of topologies obtained and evolutionary steps in a less resolved consensus tree. For these reasons, we have decided not to include these two additional taxa in the core analysis.

\section{Discussion}

Goniopholididae is formed by a complex group of basal taxa from the Jurassic and Early Cretaceous of Asia and North America, several putative goniopholidis from the Late Cretaceous of North America and two derived sister clades from the Early to mid-Cretaceous of Europe with Nannosuchus as the basal-most branch (Andrade et al., 2011; Salisbury and Naish, 2011; Buscalioni et al., 2013). These two European clades are composed of the Early Cretaceous European lineage that contains the genus Goniopholis (Node 3 ) and the Early to mid-Cretaceous assemblage (Node 4) formed by Hulkepholis, Anteophthalmosuchus and Dollo's goniopholidid, which is probably another new species of $\mathrm{An}$ teophthalmosuchus. Below we highlight the main differences and similarities within these two clades and their taxa.

\subsection{Comparisons}

Comparison of the goniopholidid (CCB-1) from Mina Corta Barrabasa with A. escuchae and H. plotos has been quite difficult. This is due to the disarticulated and fragmentary nature of the skeleton, the scarcity of cranial remains, and the difficulty of comparing the postcranial bones due to their absence in the holotypes. Nevertheless, we believe that there are sufficient morphological features that allow comparison with the European goniopholidid taxa. For this paper, in addition to the new material described herein, we have studied firsthand the skulls of A. escuchae (AR-1-1097) and H. plotos (AR-1-2045), and the postcranial skeleton of the unnamed Dollo's goniopholidid (IRSNB R47) from Bernissart
(Belgium). We have preferred not to include a comparison with the indeterminate goniopholidid AR-1-3422 from Ariño (Buscalioni et al., 2013) because this is still under study.

Within Node 4, one of the first differences of CCB-1, Anteophthalmosuchus and Dollo's goniopholidid with respect to the genus Hulkepholis is the rostral proportions. On the basis of the preserved bones of the skull and the mandible, we have been able to propose a skull reconstruction for CCB-1, which probably showed a mesorostrine condition. Most goniopholidids are mesorostrines, with the exception of a few longirostrine taxa such as Hulkepholis willetti (Salisbury and Naish, 2011). The state of $H$. plotos as a longirostrine taxon (Buscalioni et al., 2013) is questionable. Taking into account the length of the rostrum (anterior margin of orbits to tip of premaxilla $=22 \mathrm{~cm}$ ) relative to the total skull length (posterior edge of parietal to tip of premaxilla $=36 \mathrm{~cm}), H$. plotos is mesorostrine rather than longirostrine (see Appendix S1, character 5 of Andrade et al., 2011).

Despite the lack of cranial material from CCB-1, we have been able to compare bones with important characters within Goniopholididae such as the periorbital region, the skull table and the mandible.

The periorbital region of CCB-1 is very similar to that present in Node 4. CCB-1 and Node 4 lack the interorbital crest formed by the lachrymal, prefrontal and frontal (this crest is always present in Node 3). As in Node 4 and 3, CCB1 has a sulcus in front of the orbit formed at the jugal and lachrymal contact (also shared with some pholidosaurids and some atoposaurids). In CCB-1, Node 4 and Goniopholis spp., the frontal is only excluded from the secondary orbital rim, formed by the incorporated palpebral. As in Hulkepholis and Node 3, the prefrontal extends posteriorly reaching the medial borders of the orbit, with the frontal reaching the primary orbit medially and posteromedially; this character is unknown in A. escuchae and differs from A. hooleyi and Dollo's goniopholidid, where the prefrontal is longer, also reaching the posteromedial margin of the orbit. CCB-1 shares the presence of small, robust and rectangular palpebrals with Node 4, with the exception of the genus Hulkepholis; in Hulkepholis the palpebrals are as in Goniopholis, elongated and triangular in shape. CCB-1 and the rest of the taxa within Node 4 lack a ventral projection of the anterior ramus of the jugal below the orbit, differing in this respect from the rest of the goniopholidids, which have a modest projection.

The preserved bones of the skull table in CCB-1 also allow comparison of some characters within Goniopholididae. Although it is not complete, the supratemporal fenestra of CCB1 is subequal in size to the orbit; this character is shared with all of Node 4, as well as G. simus and G. kiplingi, and differs from the rest of the goniopholidids, where the fenestra is smaller than the orbit. In contrast, the supratemporal fossa is bigger than the orbit in CCB-1 and the rest of Node 4, differing in this respect from most goniopholidids. CCB-1, Node 4 and Goniopholis share the presence of square supratemporal fossae, in contrast to A. hooleyi, Dollo's goniopholidid and 
the rest of the goniopholidids, which are rounded or elliptic in shape.

The shape, disposition and structures of the skull table bars also vary within Goniopholididae. CCB-1 shares with Hulkepholis and G. simus the presence of straight and parallel lateral margins in the intertemporal bar; this bar is laterally concave in other goniopholidids. The lateral temporal bar (formed by the postorbital and squamosal) of the skull table of CCB-1 is straight in its lateral margin and slightly divergent posteriorly, a similar condition to that observed in A. escuchae; this character differs from the other goniopholidids, which have lateral margins that are parallel or sinusoidal.

The mandible of CCB- 1 is similar to that of most goniopholidids and almost identical to that in A. escuchae. The mandibles of CCB-1 and A. escuchae present a similar general morphology with a strongly pitted lateral surface; the same dental morphology; the angular gently curved below the glenoid fossa; angular-surangular suture reaching the posterior tip of the retroarticular process; well-developed surangular crest in its dorsolateral margin; forked surangular-dentary contact; absence of mandibular fenestra; and similar orientation of the retroarticular process. All of these features could support the hypothesis that they are the same taxon. The only difference is that the retroarticular process of A. escuchae is slightly posterodorsally oriented and in a more dorsal plane than the glenoid fossa. Nevertheless, this small difference could be due to ontogeny (CCB-1 is almost twice the size of A. escuchae).

Unfortunately, other important skull characters of Goniopholididae, such as the presence of a maxillary depression (common in most goniopholidids) or the development of a long and robust anterolateral process on the postorbital (diagnostic synapomorphy of Node 4 ), have not been preserved in CCB-1.

Regarding the postcranial bones of CCB-1, similarities and differences within Goniopholididae have also been observed. The osteoderms of CCB-1 lack the crest on their laterodorsal margin, a character present in most goniopholidids such as G. simus, A. hooleyi and Sunosuchus. The coracoid of CCB1 is very similar to Dollo's goniopholidid and differs from other goniopholidids such as A. hooleyi or G. simus. CCB-1 presents the anterior margin of the coracoid blade curved and more flared than the posterior margin, being clearly nonparallel; by contrast, in other goniopholidids the blade is more straight and subparallel. Comparing the forelimbs of CCB-1 with those of Dollo's goniopholidid, one of the most complete goniopholidid skeletons in existence, differences in robustness can also be observed; the carpus, metacarpus and phalanges of CCB-1 are much shorter and more robust than in Dollo's goniopholidid.

\section{Conclusions}

Specimen CCB-1 from the Albian Escucha Formation of Teruel (Spain) has been compared with other closely related
European taxa within Goniopholididae. For the first time, CCB-1, A. escuchae (AR-1-1097) and H. plotos (AR-1-2045) have been included in a cladistic analysis, showing many similarities to other European taxa such as Anteophthalmosuchus hooleyi, Hulkepholis willetti and Dollo's goniopholidid. The cladistic analysis shows two derived sister clades within Goniopholididae that consist of European taxa. These two clades are the clade formed by the Late Jurassic-Early Cretaceous (Kimmeridgian-Berriasian) lineage of Goniopholis, and the Early to mid-Cretaceous (Valanginian-Albian) clade formed by CCB-1, Anteophthalmosuchus, Hulkepholis and Dollo's goniopholidid.

The morphology of CCB-1 is clearly different from other goniopholidids described in the Early Cretaceous of Europe, such as Goniopholis. The periorbital region, skull table and mandible of CCB-1 are very similar to those of $A$. escuchae from Ariño (Teruel), a taxon from the same age, geological formation and geographical region. According to our comparisons and cladistic analysis, CCB-1 and AR-1-1097 probably belong to the same species, A. escuchae. However, in view of the presence of some morphological differences between the two taxa (probably related to ontogeny) and their fragmentary nature, and pending a firsthand study of the unnamed skull from Ariño (AR-1-3422), we prefer to classify them as Anteophthalmosuchus cf. escuchae until new and more complete material is recovered.

\section{Acknowledgements}

This work forms part of the projects CGL2010-16447, subsidized by the Spanish Ministry of Economy and Competitiveness, the European Regional Development Fund, and the Government of Aragón (Grupos Consolidados and Dirección General de Patrimonio Cultural). Thanks to Eduardo Espílez and Luis Mampel (Fundación Conjunto Paleontológico de Teruel-Dinópolis/Museo Aragonés de Paleontología, Teruel) and Anelisse Folie (IRSNB, Brussels) for access to specimens in their care. Thanks to Adela Sanmartín for the accommodation on the visit to Brussels. We thank the referees Christopher A. Brochu and Jahn Hornung for their comments. Special thanks to Miguel Moreno Azanza, Luis Miguel Sender, Jara Parrilla Bel, Penélope Cruzado Caballero, José Manuel Gasca and Rubén Contreras for participating in excavations, and to ENDESA, especially Alberto Villanueva and Concepción Dueñas, for their collaboration. We thank Rupert Glasgow who edited the text in English.

\section{References}

Aguilar, M.J., Ramírez del Pozo, J., Oriol Riba, A. (1971): Algunas precisiones sobre la sedimentación y la paleoecología del Cretácico Inferior de la zona de Utrillas-Villaroya de los Pinares (Teruel). Estudios Geológicos 27, 497-512.

Alcalá, L., Espílez, E., Mampel, L., Kirkland, J.I., Ortiga, M., Rubio, D., González, A., Ayala, D., Cobos, A., Royo-Torres, R., Gascó, F., Pesquero, M.D. (2012): A new Lower Cretaceous vertebrate bonebed 
near Ariño (Teruel, Aragón, Spain); found and managed in a joint collaboration between a mining company and a palaeontological park. Geoheritage 4, 275-286. doi: 10.1007/s12371-012-0068-y

Allen, E.R. (2012a): Analysis of North American goniopholidid crocodyliforms in a phylogenetic context. Unpublished, Theses and Dissertations, University of Iowa, Iowa, $89 \mathrm{p}$.

Allen, E.R. (2012b): Investigation of North American goniopholidid crocodyliforms in a phylogenetic context. Abstracts $72^{\text {nd }}$ Annual Meeting of the Society of Vertebrate Paleontology, Raleigh, NC. Journal of Vertebrate Paleontology 32 (supplement to 3), 55.

Andrade, M.B. de, Hornung, J.J. (2011): A new look into the periorbitalmorphology of Goniopholis (Mesoeucrocodylia: Neosuchia) and related forms. Journal of Vertebrate Paleontology 31, 352-368. doi: 10.1080/02724634.2011.550353

Andrade, M.B. de, Edmonds, R., Benton, M.J., Schouten, R. (2011): A new Berriasian species of Goniopholis (Mesoeucrocodylia, Neosuchia) from England, and a review of the genus. Zoological Journal of the Linnean Society 163, 66-108. doi: 10.1111/j.10963642.2011.00709.x

Benton, M.J., Clarck, J.M. (1988): Archosaur phylogeny and the relationships of the Crocodilia. In: M.J. Benton (ed.), The phylogeny and classification of tetrapods, 1: Amphibians, reptiles, birds. Systematics Association, Special Volume 35A. Clarendon Press, Oxford, pp. 295-338.

Bremer, O., Kear, B.P. (2013): Reassessment of the 'last' goniopholidid: Denazinosuchus kirtlandicus from the Late Cretaceous of New Mexico. Abstracts $73^{\text {nd }}$ Annual Meeting of the Society of Vertebrate Paleontology, Los Angeles, CA. Journal of Vertebrate Paleontology 33 (supplement online), pp. 93-94.

Buscalioni, A.D., Sanz, J.L. (1987): Cocodrilos del Cretácico inferior de Galve (Teruel, España). Estudios Geológicos volumen extraordinario Galve-Tremp, 23-43. doi: 10.3989/egeol.8743Extra624

Buscalioni, A.D., Pérez-Moreno, B.P., Sanz, J.L. (2003): Pattern of biotic replacement in modern crocodiles: The Upper Cretaceous fossil record. Coloquios de Paleontología 1 volumen Extraordinario, 77-93.

Buscalioni, A.D., Alcalá, L., Espílez, E., Mampel, L. (2013): European Goniopholididae from the Early Albian Escucha Formation in Ariño (Teruel, Aragón, España). Spanish Journal of Paleontology 28, 103-122.

Canudo, J.I., Ruiz-Omeñaca, J.I., Sender, L.M. (2004): Primera evidencia de un dinosaurio saurópodo en la Formación Escucha (Utrillas, Teruel), Albiense medio (Cretácico inferior). Geo-Temas 6(5), 27-30.

Canudo, J.I., Gasca, J.M., Aurell, M., Badiola, A., Blain, H.-A., Cruzado-Caballero, P., Gómez-Fernández, D., Moreno-Azanza, M., Parrilla, J., Rabal-Garcés, R., Ruiz-Omeñaca, J.I. (2010): La Cantalera: an exceptional window onto the vertebrate biodiversity of the Hauterivian-Barremian transition in the Iberian Peninsula. Journal of Iberian Geology 36, 205-224. doi: 10.5209/rev_JIGE.2010.v36.n2.8

Cervera, A., Pardo, G, Villena, J. (1976): Algunas precisiones litoestratigráficas sobre la Formación "Lignitos de Escucha". Tecniterrae 14, 25-33.

Cope, E.D. (1875): Check-list of North American Batrachia and Reptilia with a systematic list of the higher groups and an essay on geographical distribution based on the specimens in the U.S. National Museum. Bulletin of the United States National Museum 1, 1-104.

Cuenca-Bescós, G., Badiola, A., Canudo, J.I., Gasca, J.M., MorenoAzanza, M. (2011): New dryolestidan mammal from the HauterivianBarremian transition. Acta Paleontologica Polonica 56, 257-267. doi: 10.4202/app.2009.0157

Gea, G.A. de, Rodríguez-López, J.P., Meléndez N., Soria, A.R. (2008): Bioestratigrafía de la Fm. Escucha a partir del estudio de foraminíferos planctónicos y nanofósiles en el sector de Alcaine, Teruel. Geogaceta 44, 115-118.

Goloboff, P.A., Farris, J.S., Nixon, K.C. (2008): TNT, a free program for phylogenetic analysis. Cladistics 24, 774-786. doi:10.1111/j.10960031.2008.00217.x

Halliday, T., Andrade, M.B., Benton, M.J., Efimov, M.B. (in press): A re-evaluation of goniopholidid crocodylomorph material from Central Asia: Biogeographic and phylogenetic implications. Acta Palaeontologica Polonica. doi: 10.4202/app.2013.0018

Iordansky, N.N. (1973): The skull of the Crocodylia. In: C. Gans, T.S. Parsons (eds.), Biology of the Reptilia, volume 4 (Morphology D). Academic Press, London, pp. 201-262.

Irmis, R.B., Hutchison, J.H., Sertich, J.J.W., Titus, A.L. (2013): Crocodyliforms from the Late Cretaceous of Grand Staircase-Escalante National Monument and Vicinity, Southern Utah, U.S.A. In: A.L. Titus, M.A. Loewen (eds.), At the top of the Grand Staircase: the Late Cretaceous of southern Utah. Indiana University Press, Bloomington, pp. 424-444.

Kirkland, J.I., Alcalá, L., Loewen, M.A., Espílez, E., Mampel, L., Wiersma, J.P. (2013): The basal nodosaurid ankylosaur Europelta carbonensis n. gen., n. sp. from the Lower Cretaceous (Lower Albian) Escucha Formation of Northeastern Spain. PLoS ONE 8 (12): e80405. doi: 10.1371/journal.pone.0080405

Lucas, S.G., Sullivan, R.M. (2003): A new crocodylian from the Upper Cretaceous of the San Juan Basin, New Mexico. Neues Jarbuch für Geologie und Paläontologie, Montashefte 2, 109-119.

Lucas, S.G., Sullivan, R.M., Spielmann, J.A. (2006): Late Cretaceous crocodylians from the San Juan Basin, New Mexico. In: S.G Lucas, R.M. Sullivan (eds.), Late Cretaceous Vertebrates from the Western Interior. New Mexico Museum of Natural History and Science Bulletin 35, 249-252.

Martin, J.E., Delfino, M. (2010): Recent advances in the comprehension of the biogeography of Cretaceous European eusuchians. Palaeogeography, Palaeoclimatology, Palaeoecology 293, 406-418. doi: 10.1016/j.palaeo.2009.10.021

Martín. L., Leyva, E., Arteaga, R. (1986): Síntesis geológico-minera de las cuencas lignitiferas de Oliete-Ariño, Utrillas-Aliaga y Castellote. Instituto Geológico y Minero de España, Servicio de Publicaciones del Ministerio de Industria y Energía, Madrid, 231 p.

McDonald, A.T., Espílez, E., Mampel, L., Kirkland, J.I., Alcalá, L. (2012): An unusual new basal iguanodont (Dinosauria: Ornithopoda) from the Lower Cetaceous of Teruel, Spain. Zootaxa 3595, 61-76. doi: $10.11646 /$ zootaxa.3609.5.8

Mook, C.C. (1921): Notes on the postcranial skeleton in the Crocodilia. Bulletin of the American Museum of Natural History 44, 67-100.

Nascimento, P.M., Zaher, H. (2010): A new species of Baurusuchus (Crocodyliformes, Mesoeucrocodylia) from the Upper Cretaceous of Brazil, with the first complete postcranial skeleton described for the family Baurusuchidae. Papéis Avulsos de Zoologia 50, 323-361. doi: 10.1590/S0031-10492010002100001

Ortega F., Moratalla J.J., Buscalioni A.D., Sanz J.L., Jiménez, S., Valbuena J. (1996): Sobre la presencia de un cocodrilo fósil (Crocodylomorpha: Neosuchia: Goniopholis sp.) en la Cuenca de Cameros (Cretácico Inferior: Vadillos-San Román de Cameros, La Rioja. Zubia 14, 113-120.

Owen, R. (1842): Report on British fossil reptiles. Part II. Report of the British Association for the Advancement of Science 11, 60-204.

Pritchard, A.C., Turner, A.H., Allen, E.R., Norell, M.A. (2013): Osteology of a North American goniopholidid (Eutretauranosuchus delfsi) and palate evolution in Neosuchia. American Museum Novitates 3783, 1-56. doi: 10.1206/3783.2

Puértolas-Pascual, E., Canudo, J.I. (2013): Dermal skeleton of a lower Albian goniopholidid (Crocodylomorpha, Neosuchia) from Andorra (Teruel, Spain): biomechanical implications. Abstracts VI Jornadas Internacionales sobre Dinosaurios y su Entorno, Salas de los Infantes, Burgos, pp. 115-117.

Puértolas, E., Canudo, J.I., Cruzado-Caballero, P. (2011): A new croco- 
dylian from the Late Maastrichtian of Spain: Implications for the initial radiation of crocodyloids. PLOS ONE 6 (6): e20011. doi: 10.1371/ journal.pone.0020011

Puértolas-Pascual, E., Moreno-Azanza, M., Canudo, J.I. (2012): Primer registro de un cocodrilomorfo (Neosuchia, Goniopholididae?) en la Formación Escucha (Albiense inferior) de la mina Corta Barrabasa (Teruel). Resúmenes X Encuentro de Jóvenes Investigadores en Paleontología, Sot de Chera, Valencia, pp. 94-96.

Puértolas-Pascual, E., Canudo, J.I., Moreno-Azanza, M. (2014): The eusuchian crocodylomorph Allodaposuchus subjuniperus sp. nov., a new species from the latest Cretaceous (upper Maastrichtian) of Spain. Historical Biology 26, 91-109. doi: 10.1080/08912963.2012.763034

Querol, X., Salas, R., Pardo, G., Ardèvol, L. (1992): Albian coal-bearing deposits of the Iberian Range in northeastern Spain. In: P. McCabe, J. Parrish (eds.), The controls on distribution and quality of Cretaceous coals. Bulletin of the Geological Society of America Special Papers 267, 193-208. doi: 10.1130/SPE267-p193

Ruiz-Omeñaca, J.I., Canudo, J.I., Aurell, M., Badenas, B., Cuenca-Bescós, G., Ipas, J. (2004): Estado de las investigaciones sobre los vertebrados del Jurásico superior y el Cretácico inferior de Galve (Teruel). Estudios geológicos 60, 179-202. doi: 10.3989/egeol.04603-6

Salisbury, S.W., Frey, E. (2001): A biomechanical transformation model for the evolution of semi-spheroidal articulations between adjoining vertebral bodies in crocodilians. In: G.C. Grigg, F. Seebacher, C.E. Franklin (eds.), Crocodilian biology and evolution. Surrey Beatty and Sons, Chipping Norton, pp. 85-134.

Salisbury, S.W., Naish, D. (2011): Crocodilians. In: D.J. Batten (ed.), English Wealden Fossils. The Palaeontological Association, London, pp. 305-369.

Salisbury, S.W., Willis, P.M.A., Peitz, S., Sander, P.M. (1999): The crocodilian Goniopholis simus from the Lower Cretaceous of northwestern Germany. Special Papers in Palaeontology 60, 121-148.

Salisbury, S.W., Molnar, R.E., Frey, E., Willis, P.M.A. (2006): The origin of modern crocodyliforms: new evidence from the Cretaceous of Australia. Proceedings of the Royal Society B 273, 2439-2448. doi: 10.1098/rspb.2006.3613

Schwarz, D. (2002): A new species of Goniopholis from the Upper Jurassic of Portugal. Palaeontology 45, 185-208. doi: 10.1111/14754983.00233

Schwarz-Wings, D., Rees, J., Lindgren, J. (2009): Lower Cretaceous Mesoeucrocodylians from Scandinavia (Denmark and Sweden). Cretaceous Research 30, 1345-1355. doi: 10.1016/j.cretres.2009.07.011

Sereno, P.C., Larsson, H.C.E., Sidor, C.A., Gabo, B. (2001): The giant crocodyliform Sarcosuchus from the Cretaceous of Africa. Science 294, 1516-1519. doi:10.1126/science.1066521

Tibert, N.E., Colinm, J-P., Kirkland, J.I., Alcalá, L., Martín-Closas, C. (2013): Lower Cretaceous ostracods from the Escucha Formation, Ariño, Spain (Iberian Basin); Paleontological implications for age and depositional environment. Micropaleontology 9, 83-91.

Villanueva-Amadoz, U. (2009): Nuevas aportaciones palinoestratigráficas para el intervalo Albiense-Cenomaniense en el Sector NE de la Península Ibérica. Implicaciones paleogeográficas y paleoclimáticas. Unpublished Doctoral thesis, Universidad de Zaragoza, Zaragoza, $632 \mathrm{p}$.

Walker, A.D. (1970): A revision of the Jurassic reptile Hallopus victor (Marsh), with remarks on the classification of crocodiles. Philosophical Transactions of the Royal Society B 257, 323-372. doi:10.1098/ rstb. 1970.0028

Whetstone, K.N., Whybrow, P.J. (1983). A “cursorial” crocodilian from the Triassic of Lesotho (Basutoland), southern Africa. Occasional Papers of the Museum of Natural History University of Kansas 106, 1-37.

Wiman, C. (1932): Goniopholis kirtlandicus n. sp. aus der oberen Kreide in New Mexico. Bulletin of the Geological Institution of the University of Uppsala 23, 181-189.

Wu, X.-C., Brinkman, D.B., Russell, A.P. (1996): Sunosuchus junggarensis sp. nov. (Archosauria: Crocodyliformes) from the Upper Jurassic of Xinjiang, People's Republic of China. Canadian Journal of Earth Sciences 33, 606-630. doi: 10.1139/e96-045

\section{Appendix 1}

New character-taxon codes included in the matrix of Andrade et al. (2011) for the phylogenetic analysis:

Anteophthalmosuchus cf. escuchae (CCB-1):

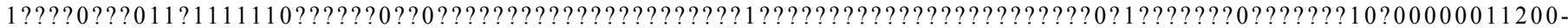
$101 ? ? ? 010102 ? ? ? 1 ? ? 0 ? ? 0 ? ? 02 ? ? ? ? 0 ? 0000 ? 10 ? ? ? ? 00 ? 20 ? 0 ? 10110 ? ? ? ? 110100002 ? 112 ? 0 ? 222 ? ? ? ? ? ? ? ? ? ? ? ? ? ? ? ? ? ? ? ? ? ? ? ? ? ? ? ? ? ? ? ? ? ? ? ? ? ? ? ? ? ? ? ? ? ? ? ? ? ? ? ? ? ? ?$

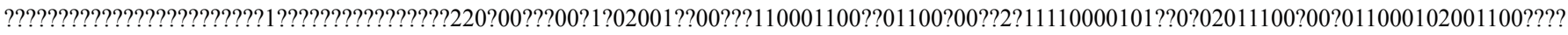
???????2?02?00??????10?100?0?00000????1?1100???????????????00?0?????110011???21?00001010?0??????

Hulkepholis plotos (AR-1-2045):

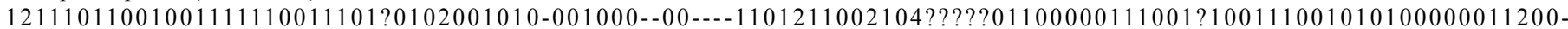
101 ? 100101020101 ? ? 0 ? ? 11110 ? 100010100 ? 000000012210000100001010110 ? ? ? 110110002 ? 110001112 $10001 ? 1 ? 011 ? 0002000112101 ? 200001 ? ? ? ? ? 00 ? 0011102 ? 020101 ? 000000110001900100010010100 ? 11 ? 1000 ? ? ? ? ? 000 ? 1220100 ? ? ? 0101 ? 02001 ? ? 00---$

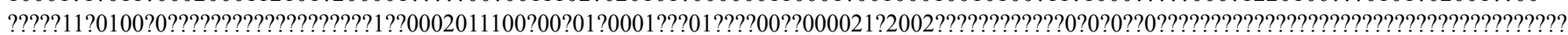
?????????????????????????????

Anteophthalmosuchus escuchae (AR-1-1097):

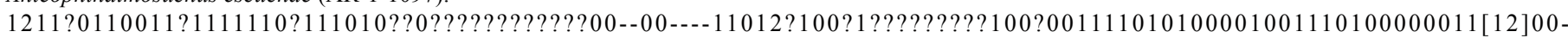

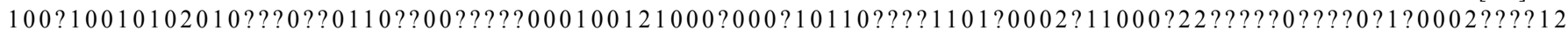

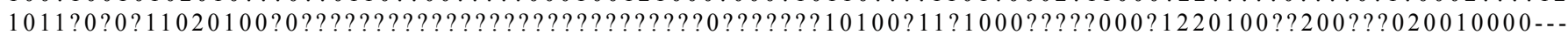
11000110010011001001?2011110000101??00020112101000011000102001100?00????0??112002200001010010010000?00????????????????????????????? ????????????????????????????????

Anteophthalmosuchus escuchae (AR-1-1097 + CCB-1):

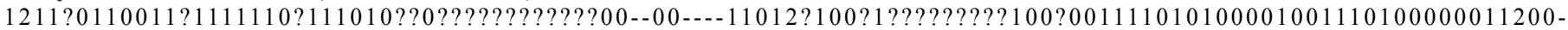
$10[01] ? 100101020101 ? ? 0 ? ? 01102 ? 00 ? 0 ? 000001001210002000 ? 10110 ? ? ? ? 110100002 ? 11000 ? 222 ? ? ? ? 0 ? ? ? ? 0 ? 1 ? 0002 ? ? ? ? 121011 ? 0 ? 0 ? 11020100 ? 0 ? ? ? ? ? ? ? ? ? ?$ ?????????????????0???????10100?11?1000?????000?1220100??200?1?020010000--11000110010011001001?2011110000101??0002011[12][01]010000110 00102001100?00????0??112002200001010010010000?00000????1?1100????????????????00?0??????110111????21?00001010?0?????? 